\title{
Research on Essential and Possibility of applying Sustainable Business Reporting at companies under Vietnam Oil and Gas Group Management (Petro Vietnam)
}

\author{
Authors: Nguyen Xuan Hung ${ }^{1}$; Le Anh Tuan ${ }^{2}$ \\ University of Economics, Ho Chi Minh City, Viet Nam \\ Duy Tan University, Da Nang City, Viet $\mathrm{Nam}^{2}$
}

< DOI: 10.26821/IJSRC.6.12.2018.61203 >

\begin{abstract}
:
The purpose of this research was to assess current stage of Sustainable Business Reporting (including 3 perspectives: economy, social, and environment) and also assess possibilify of applying Sustainable Business Reporting at companies belonging to the Vietnam Oil and Gas Group. Basing on foundation from researches around the world with regard to Sustainable Business, research group points out the essential of establishing Sustainable Business Reporting at Vietnamese companies in general, more specifically companies belonging to the Vietnam Oil \& Gas Group. Then, group will apply research methodologies to assess possibility of applying Sustainable Business Reporting at these companies.
\end{abstract}

Key words: Sustainable Business Reporting, Petro, Vietnam

\section{Introduction}

Sustainable development in general and sustainable development in particular are issues that are being investigated, analyzed, and discussed by researchers not only in in Vietnam but around the world. In recent years, countries have regularly organized seminars or global forums related to the issue of sustainable development reporting, indicators related to sustainable development as well as the role of accounting in the sustainable development of the business. In developed countries such as the United Kingdom, the United States of America, Australia, etc., the issue of sustainable development has been set long since the 70s of the last century.

According to Global Reporting Initiative (GRI) guidelines, a typical report should address the following areas: Vision and Strategy; Company profile; Management structure and management system; GRI content index; and Performance Standards (Economic, Social and Environmental) (Adams and Narayanan, 2007). Operational criteria are divided into "core" or "additional". The 'core' criterion is used to define common applicable criteria and is assumed to be important for most companies while 'additional' criteria refer to emerging practices. It may or may not apply to all businesses.

2. Outstanding research around the world on sustainable development reporting in petroleum industry

There are many theoretical studies on sustainable development related to the field of accounting. In particular, there has been a lot of empirical research and testing of factors affecting the establishment and dissemination of sustainable development information in the petroleum industry. These studies were conducted in different countries, different types of businesses and at different times. But it is clear that the issue of sustainable information disclosure is influenced by a number of key factors. A few related studies are summarized below:

First, Craswell, A. T. \& Taylor, S. L. (1992). Discretionary disclosure of oil and gas companies: an economic analysis. Journal of Business, Finance and Accounting, 19 (2), 295-308. The article strives to increase our understanding of voluntary disclosure in general and in particular the decision of Australian oil companies to disclose information in their annual reports. They are about the amount of oil reserves they can estimate. Unlike some previous 
Volume 6 Issue12 December 2018

studies, the authors of the article focused on a decision to disclose information in a particular industry. The paper's authors' work is based on the view that the decision to provide information in the annual report on enterprise-dependent reserves faces stakeholders (Uensen and Meckling, 1976). In this context, the decision to disclose information is seen as a means to minimize the costs involved with the parties. Accordingly, the authors consider that the disclosure of information depends on the following factors: (1) investment leverage, (2) company size, (3) cash flow risk, (4) quality of auditors, (5) separation of ownership and control, and (6) expected costs of issuance.

Second, Hackston, D. \& Milne, M. J. (1996). Some determinants of social and environmental disclosures in New Zealand companies. Accounting, Auditing and Accountability Journal 9 (1): 77-108. The authors use a mixed approach to synthesize factors that influence the disclosure of environmental and social information by businesses in New Zealand. The independent variables that the authors propose influencing the dependent variable disclosure of social and environmental information are: (1) firm size, (2) profitability, (3) businesses, and (4) countries provided by businesses. After pointing out the factors that affect the publication of environmental and social information, the authors argue that there are a number of factors that would affect the publication of social and environmental information: the company's capital, the company's operating capitals, the managerial views of the manager and the corporate social responsibility committee. Taking the sample of 50 large firms in the New Zealand stock market by the end of 1992, the accurate sample of 47 firms indicated that all four factors had little effect on the disclosure of information, environment and society in New Zealand.

Third, José V. Frias-Aceituno, Lázaro Rodríguez-Ariza \& Isabel M. Garcia-Sánchez (2012). Explanatory Factors of Integrated Sustainability and Financial Reporting. Business Strategy and the Environment. The authors point out that there are five main factors influencing the development of sustainable development reporting based on theories: 1. Company size: The larger the scale, the more necessary is it to provide special information that is nonfinancial (social, environmental), 2. Profitability: It is a complex matter to make profit through the Sustainable Development Report. Profitable companies will disclose information to distinguish themselves from less successful businesses, to minimize the cost of capital mobilization and to prevent the stock price drop. 3. Business: Business is a variable used to calculate the amount of information provided by companies. Assume that companies operating in the same industry will adopt similar models of information they provide to the outside world. Otherwise, this may explain that the market is untrustworthy. 4. Industry Position: If the business sector is a monopoly, more transparency about the impact of the business should be made public. 5. Growth Opportunities: The authors point out that the corporate transparency policy is a specific trait that affects the growth benefits of that company. These factors mean that businesses can only receive capital from outside by giving more accurate information. In addition to the above five factors, this study also collects information on GRI-compliant enterprises' ratings, country variables, and time of analysis.

Fourth, Ndukwe O. Dibia \& John Chik Nwuchekwa (2015). Determinants of Environmental Disclosures in Nigeria: A Case Study of Oil and Gas Companies. International Journal of Finance and Accounting, 4(3): 145-152 The paper discusses the determinants of environmental disclosure in Nigeria: Case Studies of Oil Companies. This study is an empirical analysis of the determinants of environmental information disclosure using oil and gas companies in Nigeria. Specifically, the research objective is to examine the effect of enterprise size, profitability, leverage and type of auditing firm on environmental disclosure. Cross-sectional design was used to conduct the study. A sample of 15 companies obtained from the oil and gas industry on the Nigerian stock market in the fiscal years 2008-2013 was used for this study. Secondary data were derived from the annual reports of sampled companies and regression techniques used as data analysis methods. The findings of the study indicated the following: First, there is a significant relationship between the size of the company and the corporate social responsibility statement; Second, there is no significant relationship between profitability and disclosure of company information; Third, there is no relationship between business leverage and corporate social responsibility and Finally, there is no significant relationship between the type of audit firm and the corporate social responsibility statement. The study concluded that the hypothesis of making a voluntary, transparent report is a weakness for companies reporting their impact on the environment. The study recommends that businesses should be encouraged to disclose environmental information more and more transparently. 
Table 1.1 Summary table of foreign studies

You should include a column in the table as 'Source' which should have the name of the journal, volume and page numbers.

\begin{tabular}{|c|c|c|c|}
\hline Year / author(s) & Name of the study & Research method(s) & Results \\
\hline $\begin{array}{l}\text { 1981/ Trotman, K.T., } \\
\text { Bradley, G.W. }\end{array}$ & $\begin{array}{lr}\text { Associations } & \text { between } \\
\text { social } & \text { responsibility } \\
\text { disclosure } & \text { and } \\
\text { characteristics } & \text { of } \\
\text { companies } & \end{array}$ & $\begin{array}{l}\text { The main research } \\
\text { method is mixed method. } \\
\text { Use of background theory } \\
\text { to show the factors. }\end{array}$ & $\begin{array}{l}\text { - The larger the scale, the } \\
\text { higher the level of } \\
\text { information disclosure. } \\
\text { - Companies that want to } \\
\text { minimize risk in their } \\
\text { business should disclose } \\
\text { social responsibility } \\
\text { information } \\
\text { - Companies in various } \\
\text { fields face social pressures } \\
\text { that require disclosure of } \\
\text { business and production } \\
\text { information that affects the } \\
\text { social environment. }\end{array}$ \\
\hline $\begin{array}{l}\text { 1996/ Deegan, C., } \\
\text { Gordon, B. }\end{array}$ & $\begin{array}{ll}\text { A study of the } \\
\text { environmental } & \text { disclosure } \\
\text { practices of } & \text { Australian } \\
\text { corporations } & \end{array}$ & $\begin{array}{l}\text { Mixed methodology. } \\
\text { Qualitative research } \\
\text { method based on } \\
\text { background theories } \\
\text { provides the elements. } \\
\text { Quantitative methods } \\
\text { measure the level of such }\end{array}$ & $\begin{array}{l}\text { Evaluate whether the release } \\
\text { of environmental } \\
\text { information is objective, } \\
\text { increasing the quality of } \\
\text { information and the } \\
\text { transparency of information } \\
\text { disclosure. }\end{array}$ \\
\hline $\begin{array}{l}\text { 2014/ Vinal } \\
\text { Mistry, Umesh } \\
\text { Sharma, Mary Low }\end{array}$ & $\begin{array}{l}\text { "Management } \\
\text { accountants perception } \\
\text { of their role in } \\
\text { accounting for } \\
\text { sustainable development: } \\
\text { An exploratory study }\end{array}$ & $\begin{array}{l}\text { Qualitative research } \\
\text { methods. Use the basis of } \\
\text { background theory to } \\
\text { gather information. }\end{array}$ & $\begin{array}{l}\text { Management accounting } \\
\text { staff in small and medium } \\
\text { enterprises have difficulty in } \\
\text { developing and providing } \\
\text { information related to } \\
\text { sustainable development } \\
\text { compared to accountants in } \\
\text { enterprises of scale bigger. }\end{array}$ \\
\hline $\begin{array}{l}\text { 2016/ GRI-Global } \\
\text { Reporting Initiative }\end{array}$ & $\begin{array}{l}\text { G4 Sustainability } \\
\text { Reporting Guidelines }\end{array}$ & $\begin{array}{l}\text { Qualitative } \\
\text { methods. }\end{array}$ & $\begin{array}{l}\text { Develop a set of indicators } \\
\text { related to sustainable } \\
\text { development of enterprises } \\
\text { in a general way. Helps } \\
\text { enterprises to build on their } \\
\text { sustainable development } \\
\text { indicators. }\end{array}$ \\
\hline Zabihollah & $\begin{array}{l}\text { Business sustainability } \\
\text { research: A theoretical and } \\
\text { integrated perspective }\end{array}$ & $\begin{array}{l}\text { Qualitative method. Use } \\
\text { of background theory and } \\
\text { synthesis of previous } \\
\text { studies. }\end{array}$ & $\begin{array}{l}\text { Introduce five basic issues } \\
\text { related to sustainable } \\
\text { development of the } \\
\text { enterprise: } \\
\text { governance, society, ethics } \\
\text { and environment. Synthesize } \\
\text { five main lines of research } \\
\text { related to sustainable } \\
\text { development at the } \\
\text { enterprise. }\end{array}$ \\
\hline
\end{tabular}


Volume 6 Issue12 December 2018

\begin{tabular}{|c|c|c|c|}
\hline $\begin{array}{l}\text { 1989/Ahmed } \\
\text { Belkaoui, Philip G. } \\
\text { Karpik }\end{array}$ & $\begin{array}{l}\text { Determinants of the } \\
\text { Corporate Decision to } \\
\text { Disclose Social } \\
\text { Information }\end{array}$ & Quantitative methods. & $\begin{array}{l}\text { The decision to disclose } \\
\text { social information is } \\
\text { influenced by four factors: } \\
\text { social effects, political } \\
\text { views, financial indicators } \\
\text { and economic efficiency of } \\
\text { enterprises. }\end{array}$ \\
\hline $\begin{array}{l}\text { 1992/ Craswell, A. } \\
\text { T., Taylor, S. L. }\end{array}$ & $\begin{array}{l}\text { Discretionary disclosure of } \\
\text { reserves by oil and gas } \\
\text { companies: an economic } \\
\text { analysis }\end{array}$ & $\begin{array}{l}\text { Mixed method. Use the } \\
\text { verification model. }\end{array}$ & $\begin{array}{l}\text { The disclosure of the level of } \\
\text { oil reserves at Australian } \\
\text { businesses is influenced by } \\
\text { factors such as the size of the } \\
\text { company, the expected costs } \\
\text { incurred. }\end{array}$ \\
\hline $\begin{array}{l}\text { 1996/ Hackston D., } \\
\text { Milne, M.J. }\end{array}$ & $\begin{array}{l}\text { Some determinants of } \\
\text { social and environmental } \\
\text { disclosures in New Zealand } \\
\text { companies }\end{array}$ & $\begin{array}{l}\text { Mixed method. } \\
\text { Qualitative methodology } \\
\text { through the synthesis of } \\
\text { materials out of the } \\
\text { factors. }\end{array}$ & $\begin{array}{l}\text { There are four factors that } \\
\text { affect the disclosure of social } \\
\text { and } \\
\text { information: corporate size, } \\
\text { profitability, business lines } \\
\text { and national ownership of } \\
\text { enterprises and enterprises } \\
\text { are responsible for reporting. }\end{array}$ \\
\hline $\begin{array}{l}\text { 2012/ José V. Frias- } \\
\text { Aceituno, Lázaro } \\
\text { Rodríguez-Ariza và } \\
\text { Isabel M. Garcia- } \\
\text { Sánchez }\end{array}$ & $\begin{array}{l}\text { Explanatory } \quad \text { Factors of } \\
\text { Integrated Sustainability } \\
\text { and Financial Reporting }\end{array}$ & & $\begin{array}{l}\text { The authors point to the } \\
\text { factors that influence the } \\
\text { publication of sustainable } \\
\text { development information } \\
\text { based on prior research: size, } \\
\text { profitability, business sector, } \\
\text { business location, growth } \\
\text { opportunities. Also referring } \\
\text { to the GRI rating. }\end{array}$ \\
\hline $\begin{array}{lr}\text { 2013/(Renard } & \text { Y.J. } \\
\text { Siew, Maria } & \text { C.A. } \\
\text { Balatbat, David } & \text { G. } \\
\text { Carmichael } & \end{array}$ & $\begin{array}{l}\text { The relationship between } \\
\text { sustainability practices } \\
\begin{array}{l}\text { and financial } \\
\text { performance of } \\
\text { construction companies }\end{array}\end{array}$ & $\begin{array}{l}\text { Qualitative } \\
\text { methods. }\end{array}$ & $\begin{array}{l}\text { Demonstrates a positive } \\
\text { impact when businesses } \\
\text { present financial information } \\
\text { (environmental, occupational } \\
\text { health and safety, etc.) }\end{array}$ \\
\hline $\begin{array}{l}\text { 2015/ Ndukwe O. } \\
\text { Dibia, John Chika } \\
\text { Onwuchekwa }\end{array}$ & $\begin{array}{l}\text { Determinants of } \\
\text { Environmental Disclosures } \\
\text { in Nigeria: A Case Study of } \\
\text { Oil and Gas Companies }\end{array}$ & Mixed method. & $\begin{array}{l}\text { There are only two factors, } \\
\text { company size and } \\
\text { profitability, that affect the } \\
\text { disclosure of corporate social } \\
\text { responsibility information. } \\
\text { Two factors are business } \\
\text { leverage and the quality of } \\
\text { the audit firm does not affect } \\
\text { disclosure. }\end{array}$ \\
\hline
\end{tabular}

\section{A need to establish and publish information related to sustainable development at} enterprises belonging to the Vietnam National Oil and Gas Group

\subsection{Economic impact}

According to financial reports of Vietnam Petroleum Group (Petrolimex) to the State Securities Commission, in the first nine months of 2017, Petrolimex paid VND 28,299 billion, up 16.1\% over the same period in 2016.

In addition, the consolidated net revenue of Petrolimex member units in all fields of business: petroleum, gas, lubricants, petroleum transportation, design, engineering, construction, insurance etc. is 112.427 billion, up $27.7 \%$ over the same period in 2016. The revenue increased mainly due to the increase in world crude oil price (WTI); the average 
Volume 6 Issue12 December 2018

of 9 months in 2017 is 49.36 USD / barrel, up 19.5\% over the same period in 2016 (average price in 9 months of 2016 is $41, \$ 31$ per barrel). Total consolidated profit before tax was VND3,546 billion, achieving $75.7 \%$ of the plan and $87.3 \%$ of the same period last year.

Specifically, profit before tax of petroleum business of the group reached 1,814 billion, equivalent to $51.2 \%$ of total consolidated profit. Non-petroleum business achieved VND 1,732 billion, equivalent to $48.8 \%$ of total consolidated profit (petrochemical, bitumen, chemicals reached VND 507 billion, VND 141 billion; aviation: 269 billion, insurance, bank 162 billion ...).

Total profit after tax in the first nine months of 2017 reached VND 2,906 billion. Of which, the Group's profit in consolidated profit was VND2,546 billion. The rate of after-tax profit on consolidated equity is $12.5 \%$.

In the fourth quarter of 2017, Petrolimex will carry out the business of RON 92 E5 nationwide instead of RON 92 gas from 1/1/2018 according to Decision 53/2012 / QD-TTg dated 22/11/2012 of the Prime Minister. Prime Minister promulgated a roadmap for applying the ratio of bio-fuel mix to traditional fuels; Evaluation and selection of clean diesel business in Euro IV, Euro V from 1/1/2018 according to Decision 49/2011 / QD-TTg dated 1 September 2011 of the Prime Minister on the stipulation of roadmap Applying emission standards to automobiles and motorcycles for new assembly and import.

\subsection{Environmental Impact}

The impact of the petrol business on the environment is very great, but the control of environmental issues such as control of emissions, air pollution, water pollution etc. are still facing many inadequacies. The effects of emissions generated by the petrol companies when selling these products to consumers increase the amount of harmful emissions in the air, which in turn, results in reduced air quality, which causes respiratory diseases in the people. The consequence of excessive use of petroleum is also a major cause of global warming, climate change, and so on. Until now, there has been no official organization in Vietnam. This affects the use of gasoline to the whole society and is almost indifferent to these hazards to the environment. Petroleum trading is one of the most complex areas, affecting many aspects of the economy, the petrol business in the residential areas also cause gasoline vapor pollution. It can cause a lot of harm to the health of people around because the volatile nature of gasoline. Water pollution in petroleum storage facilities, especially when cleaning of these tanks, the huge amount of waste water if not thoroughly treated, will make an adverse impact on the ecosystem. Not to mention the case of risk from the oil spill incident which will also harm the water environment, causing imbalance in natural ecosystems affecting sustainable development. The above information (impact on environmental pollution) is not disclosed clearly in the reports of the Group as well as reports of the relevant authorities.

\subsection{Social impact}

The continuous change in petrol price is mainly driven by the increasing trend that businesses and people do not have time to prepare and adjust the use of gasoline, thus adversely affecting the production plan.

In the short term, there are obvious negative factors such as consumer psychology disturbance, price pressure on commodities related to gasoline use, shock on the market evidence etc., which are unfavorable for the business sector as the input factor increases and most importantly has the direct impact on the consumer price index (CPI).

However, in the longer term, petrol price hikes have shown positive signs, namely the reduction of the fiscal deficit due to tax or foreign borrowing, reduction in petrol smuggling, prevention of speculative gasoline profiteering, and avoidance of distortions in the market due to the form of subsidies (e.g., stabilization funds) make up. In addition, rising petrol prices will make businesses adjust their economic behavior towards more fuel efficient and efficient use.

The issue of consumer price index (CPI) has been analyzed by economists. Accordingly, petroleum has "weight" of $2 \%$ in the CPI overall price. This means that the $20 \%$ increase in gasoline price in Vietnam will directly affect the CPI: $20 \%$ multiplied by $2 \%$ is about $0.4 \%$.

On the other hand, gasoline accounts for nearly $2.5 \%$ of household expenditures. So, when gasoline prices rise by $20 \%$, the real expenditure budget of the people in general decreases by about $0.5 \%$.

In summary, the Vietnam National Oil and Gas Group (PetroVietnam) has a wide range of operations, contributing a large amount of money to national exchequer. In addition, petroleum trading companies belonging to the group have a great deal of influence on the environment and society. Therefore, the establishment and publication of indicators related to sustainable development is a very important task to ensure the trust of customers, investors and the whole society. 
Volume 6 Issue12 December 2018

\section{Status of sustainable information disclosure at enterprises belonging to Vietnam Petroleum Group}

Vietnam National Petroleum Group, or Petrolimex (formerly the Vietnam National Petroleum Corporation, formerly the Vietnam National Petroleum Corporation Grease Oil), was established on December 1, 2011 under the Decree of the Ministry of Trade and was re-established under Decision No. 828 / QD-TTg dated 31 May 2011 of the Prime Minister of Vietnam. Petrolimex is a special-sized state-owned enterprise, securing a large share of the country's petrol market.

Vietnam Oil and Gas Group has 42 member companies, 34 branches and enterprises belonging to $100 \%$ stateowned member companies, 23 joint-stock companies, 3 companies Foreign joint venture and 1 branch in Singapore.

Being a state-owned enterprise, which is classified as special, nationwide scale, ensuring $60 \%$ market share of petroleum in the whole country, Petrolimex always plays a key role in stabilizing and developing the petroleum market, petrochemical products to meet the demand of the people, serving the cause of economic development of the country and ensuring national security.

Although it is a unit of large scale, very large market share and trading items that have a great impact on the environment and society in Vietnam. But the affiliated companies of the corporation and even the Vietnam Petroleum Group are not really interested in publishing information related to sustainable development (economic, social and environmental). In the financial statements of member companies and even corporations, only information on financial indicators are mentioned, but there is no information to clarify the impact of the petroleum business on the environment and society. This is a huge problem that can affect foreign investment in the equitisation trend and listing on the securities market of the corporation.

Investors, consumers and the general public are more concerned about how the group's business affects the health and living environment. Does the corporation use taxes (environmental protection, VAT, etc.) to reinvest in or care about environmental protection from emissions from the use of its products? In order to ensure sustainable development, the macro managers of the corporation should deyelop a roadmap to ensure that the publication of the indicators related to sustainable development is possible as soon as possible.

\section{Ability to publish sustainable development report in enterprises of Vietnam Petroleum Group}

As mentioned above, many countries have mandated or encouraged trading companies listed on the stock market to publish SDBs. Research shows that businesses that sell specialty products such as petrol, oil, etc. need voluntary disclosure. Vietnam Petroleum Group cannot be out of this trend. In order to enhance the ability to disclose this information, the Group may refer to a number of sample reports, frameworks and models used in countries around the world.

\subsection{Global Initiative Report (GRI)}

GRI was established in 1997 by the Organization for Environmental Cooperation (CERES) with the aim of creating a global sustainability reporting framework (GRI, 2011). Since then, the next two versions of the thirdgeneration GRI Guidelines have been released as G3 and G3.1 (an updated version of G3). A multi-stakeholder approach was used to create G3.1 guidelines with greater emphasis on clarity, purpose of the criteria as well as reporting process. Sector addition is the specific guide for various industries offered. Recently, a fourth generation (G4) guide has been developed. The G4 includes proposed changes to topics such as terrorism, anti-corruption and greenhouse gas (GHG) emissions. These guidelines are not legally binding and are voluntary (Adams and Narayanan, 2007).

Under the GRI guidelines, a typical report should address the following areas: vision and strategy, company profile,management structure and management system, GRI content index, and performance standards (Economic, Social and Environmental) (Adams and Narayanan, 2007). Operational criteria are divided into "core" or "complementary". The 'core' criterion is used to define common applicable criteria and is assumed to be important for most companies while 'additional' criteria refers to emerging practices. It may or may not apply to all businesses. Quality defined in the GRI Principles is a criterion that reflects "the significant economic, environmental, and social impact of a company, or significant influence on the assessments and decisions of its stakeholders. "(GRI, 2011).

\subsection{DPSIR Framework}

Kristensen (2004) defines the DPSIR framework as a causal linkage that begins with a set of motivations (i.e., economic components, human activities) transformed into stress (i.e. substance emissions, emissions), into states (such 
Volume 6 Issue12 December 2018

as physical, chemical and biological) and impacts (i.e., ecosystems, human health, functions) ultimately lead to key responses (e.g., priority, target setting and criteria) (Kristensen, 2004). This framework is an extension of the state response model of the government, Anthony Friend (OECD, 2003), in 1970 and later adopted by the Organization for Economic Co-operation and Development (OECD) (UNEP, 2006). It is currently being used as a unified approach to reporting by the European Environment Agency (EEA). Motivation is defined as the need, for example, of an individual's motivation to seek shelter, food, and water. Motivation for human activities such as transportation or food production puts pressure on the environment, such as direct emissions, waste production and noise. The direct consequence of these pressures affect environmental conditions, which can be physical, chemical or biological (air quality, water quality or soil quality). Changes in these states affect the quality of ecosystems. Due to these impacts, the reaction of both social workers and policymakers may affect any part of the DPSIR chain (Kristensen, 2004).

\subsection{Carbon Disaster Recovery (CDP)}

CDP is an independent non-profit corporation that holds one of the largest databases on the disclosure of greenhouse gas emissions, water use strategies and climate change on a global scale. The carbon disclosure rating of companies is based on the quality and completeness of their disclosures (CDP claims that these scores are not a measure of the company's performance. It does not give any judgment about a company's actions to mitigate climate change) (CDP, 2010). Factors to consider include company-specific risks and potential opportunities arising from climate change and good internal data management practices to help companies understand their emissions.

\section{Recommendations}

From the above comments and discussion, in order to adopt the publication of sustainable development report in business units of Vietnam Petroleum Group, the following specific measures should be taken:

(1). Study prevailing models and select a standard protocol for publication of sustainable development report. Specifically, according to the authors, Vietnam Oil and Gas Group should choose to publish Sustainable Development Information (GRI) according to the GRI reporting standard, but there should be additional adjustments in other institutional frameworks such as the disclosure project (CDP), DPSIR framework, etc. Some criteria may not be appropriate for the unit.

(2). Restructure the accounting apparatus in the units of the Vietnam Petroleum Corporation. Once a standard SDD format has been selected in accordance with the unit, the organizational structure of the accounting organization should be changed from member units to the corporation. Not only the publication of economic information, the accounting units must be functionally developed in that the management accounting department plays an important role in the development of the relevant forms. The collection of information related to the business situation affects the environmental and social aspects.

(3). The specific regulators are the Ministry of the Environment, the Ministry of Science and Technology and the Ministry of Finance. They should encourage companies and large corporations to provide environmental information to the commune Assembly. In addition, an institutional setting should be established to control the effects of business activities on the environment and the social responsibility of these enterprises. The role of state management of these activities is very large; it is necessary to provide to enterprises the benefits of development but it must ensure their sustainable development. There should be a mechanism to manage and control emissions in business and production, without compromising the environment in exchange for the development of an unsustainable economy.

\section{References:}

Adams, C.A., (2002). Internal organisational factors influencing corporate social and ethical reporting: beyond current theorising. Account. Audit. Account. J. 15 (2), 223e250.

Adams, C., Narayanan, V., (2007). In: O'Dwyer, B., Bebbington, J., Unerman, J. (Eds.), The 'Standardization' of Sustainability Reporting, cited in Sustainability Accounting and Accountability. Routledge, Oxen, pp. 70e85.

Ahmed Belkaoui, Philip G. Karpik, (1989). Determinants of the Corporate Decision to Disclose Social Information, Accounting, Auditing \& Accountability Journal, Vol. 2 Issue

Ahmed, K. \& Nicholls, D. (1994). The Impact of Non-Financial Company Characteristics on Mandatory Disclosure Compliance in Developing Countries: The Case of Bangladesh. The International Journal of Accounting, 29(1), 62-77

Belal, A. R. (2001). A Study of Corporate Social Disclosures in Bangladesh. Managerial Auditing Journal,16(5), 274289.

Bewley, K. \& Li, Y. (2000). Disclosure of environmental information by Canadian manufacturing companies: a voluntary disclosure perspective. Advances in Environmental Accounting and Management 1, 201-226. 
Volume 6 Issue12 December 2018

Carbon Disclosure Project (CDP), (2010). Carbon Disclosure Project 2010: Global 500 Report. CDP, UK viewed on 28 January 2013. https://www.cdproject.net/ CDPResults/CDP-2010-G500.pdf.

Carroll, A. B. (1999). Corporate social responsibility: Evolution of a definitional construct. Business and Society, 38(3), 268-295.

Connors, E. \& Gao, L. S. (2009). The impact of environmental risk on the cost of equity capital. Working paper presented at the Financial Management Association 2009 Annual Meeting.

Craswell, A. T. \& Taylor, S. L. (1992). Discretionary disclosure of reserves by oil and gas companies: an economic analysis. Journal of Business, Finance and Accounting, 19(2), 295-308.

Deegan, C. \& Rankin, M. (1999). The environmental reporting expectations gap: Australian evidence. British Accounting Review 31, 313-346.

Deegan C, Gordon B. (1996). A study of the environmental disclosure practices of Australian corporations. Accounting and Business Research 26(3):187-199.

Global Reporting Initiative (GRI), (2011). Sustainability Reporting Guidelines v3.1. GRI, Amsterdam viewed on 24 January 2013. https://www.globalreporting.org/ resourcelibrary/G3.1-Sustainability-Reporting-Guidelines.pdf.

Ndukwe O. Dibia \& John Chik Nwuchekwa (2015). Determinants of Environmental Disclosures in Nigeria: A Case Study of Oil and Gas Companies. International Journal of Finance and Accounting 4(3): 145-152

Renard Y.J. Siew, Maria C.A. Balatbat, David G. Carmichael, (2013) The relationship between sustainability practices and financial performance of construction companies, Smart and Sustainable Built Environment, Vol. 2 Issue: 1, pp.6-27.

Trotman, K. T. \& Bradley, G. W. (1981). Association between Social Responsibility Disclosure and Characteristics of Companies. Accounting, Organisations and Society, 6(4), 355-362

Vinal Mistry, Umesh Sharma, Mary Low, (2014). Management accountants' perception of their role in accounting for sustainable development: An exploratory study. Pacific Accounting Review, Vol. 26 Issue: 1/2, pp.112-133

Watts, R. L. \& Zimmerman, J. L. (1990). Positive acéounting theory: A ten year perspective. The Accounting Review, 65(1), 131-156.

WBCSD and WRI, (2004). The Greenhouse GaS Protocol, A Corporate Accounting and

Reporting Standard. WBCSD and WRI, Geneva, Switzerland viewed on 17 January 2013. http://www.ghgprotocol.org/files/ghgp/public/ghg-protocolrevised.pdf.

https://www.petrolimex.com.vn/gioi-thieu/gioithieu petrolimex/qua_trinh_hinh_thanh_va_phat_trien.html https://vi.wikipedia.org/wiki/T\%E1\%BA\%ADp_\%C4\%91o\%C3\%A0n_X\%C4\%83ng_d\%E1\%BA\%A7u_Vi\%E1\%BB $\% 87$ t_Nam 